\title{
The New Approaches on Traditional Social Policy Instruments: Greening Housing Policy
}

\author{
M.Çağlar Özdemir
}

Sakarya University

Ocak/January 2013, Cilt/Vol: 15, Sayı/Num: 1, Page: 59-69

ISSN: 1303-2860, DOI: 10.4026/1303-2860.2013.0219.x

Makalenin on-line kopyasına erişmek için:

http://www.isguc.org/?p=article\&id=502\&cilt=15\&sayi=1\&yil=2013

To reach the on-line copy of article:

http://www.isguc.org/?p=article\&id=502\&cilt=15\&sayi=1\&yil=2013

Makale İçin İletişim/Correspondence to: cozdemir@sakarya.edu.tr 


\title{
(c) $2000-2013$ \\ “İş,Güç” Endüstri İlişkileri ve İnsan Kaynakları Dergisi \\ "İş, Güç" The Journal of Industrial Relations and Human Resources
}

\author{
Ocak/January 2013, Cilt/Vol: 15, Sayı/Num: 1, Page: 59-69 \\ ISSN: 1303-2860, DOI: 10.4026/1303-2860.2013.0219.x
}

\begin{abstract}
“İş,Güç” Endüstri İlişkileri ve İnsan Kaynakları Dergisi, yılda dört kez yayınlanan hakemli, bilimsel elektronik dergidir. Çalışma hayatına ilişkin makalelere yer verilen derginin temel amacı; belirlenen alanda akademik gelişime ve paylaşıma katkıda bulunmaktadır.
\end{abstract}

“İş,Güç” Endüstri İlişkileri ve İnsan Kaynakları Dergisi'nde, 'Türkçe' ve 'Ingilizce' olarak iki dilde makale yayınlanmaktadır. Dergi ulusal ve uluslararası birçok indekste taranmaktadır. (CABELLS DIRECTORY, EBSCO SOCINDEX, INDEX ISLAMICUS, INDEX COPERNICUS, WORLDWIDE POLITICAL SCIENCE ABSTRACTS, SOCIOLOGICAL ABSTRACT, ULAKBIM SOSYAL BILIMLER VERITANI, ASOS INDEX)

\section{Editör / Editor in Chief}

Aşkın Keser (Uludağ University)

\section{Editör Yardımcıları / Co-Editors} Şenol Baştürk (Uludağ University) K.Ahmet Sevimli (Uludağ University) Gözde Yılmaz (Marmara University)

\section{Uygulama / Design}

Yusuf Budak (Kocaeli University)

\section{Tarandığı Indeksler}

ASOS INDEX

CABELLS DIRECTORY

EBSCO SOCINDEX

INDEX ISLAMICUS

INDEX COPERNICUS

SOCIOLOGICAL ABSTRACT

ULAKBIM SOSYAL BÍLIMLER

VERITANI

WORLDWIDE POLITICAL SCIENCE

ABSTRACTS

\author{
Yayın Kurulu / Editorial Board \\ Dr. Erdem Cam (ÇASGEM) \\ Yrd. Doç. Dr. Zerrin Fırat (Uludağ University) \\ Doç. Dr. Aşkın Keser (Uludağ University) \\ Prof. Dr. Ahmet Selamoğlu (Kocaeli University) \\ Yrd. Doç. Dr. Ahmet Sevimli (Uludağ University) \\ Doç. Dr. Abdulkadir Şenkal (Kocaeli University) \\ Doç. Dr. Gözde Yılmaz (Marmara University) \\ Yrd. Doç. Dr. Memet Zencirkıran (Uludağ University) \\ Ulus/ararası Danışma Kurulu / International Advisory Board \\ Prof. Dr. Ronald Burke (York University - CA) \\ Assoc. Prof. Dr. Glenn Dawes (James Cook University - AU) \\ Prof. Dr. Jan Dul (Erasmus University - NL) \\ Prof. Dr. Alev Efendioğlu (University of San Francisco - USA) \\ Prof. Dr. Adrian Furnham (University College London - UK) \\ Prof. Dr. Alan Geare (University of Otago - NZ) \\ Prof. Dr. Ricky Griffin (TAMU-Texas A\&M University - USA) \\ Assoc. Prof. Dr. Diana Lipinskiene (Kaunos University - LT) \\ Prof. Dr. George Manning (Northern Kentucky University - USA) \\ Prof. Dr. William L. Murray (University of San Francisco - USA) \\ Prof. Dr. Mustafa Özbilgin (Brunel University - UK) \\ Assoc. Prof. Dr. Owen Stanley (James Cook University - AU) \\ Prof. Dr. Işık Urla Zeytinoğlu (McMaster University - CA) \\ Ulusal Danışma Kurulu / National Advisory Board \\ Prof. Dr. Yusuf Alper (Uludağ University) \\ Prof. Dr. Veysel Bozkurt (İstanbul University) \\ Prof. Dr. Toker Dereli (Işık University) \\ Prof. Dr. Nihat Erdoğmuş (Şehir University) \\ Doç. Dr. Mustafa Kurt (Yalova University) \\ Prof. Dr. Ahmet Makal (Ankara University) \\ Prof. Dr. Süleyman Özdemir (İstanbul University) \\ Prof. Dr. Ahmet Selamoğlu (Kocaeli University) \\ Prof. Dr. Nadir Suğur (Anadolu University) \\ Prof. Dr. Nursel Telman (Maltepe University) \\ Prof. Dr. Cavide Uyargil (Istanbul University) \\ Prof. Dr. Engin Yıldırım (Constitutional Court of Turkey) \\ Doç. Dr. Arzu Wasti (Sabancı University)
}

Dergide yayınlanan yazılardaki görüşler ve bu konudaki sorumluluk yazarlarına aittir. Yayınlanan eserlerde yer alan tüm içerik kaynak gösterilmeden kullanılamaz.

All the opinions written in articles are under responsibilities of the authors. The published contents in the articles cannot be used without being cited. 


\title{
The New Approaches on Traditional Social Policy Instruments: Greening Housing Policy
}

\author{
M.Çağlar Özdemir
}

Sakarya University

\begin{abstract}
This study aims to look at the housing policy which is one of the most important instruments of social policies from the perspective of green economics. The study begins to form the connection between the structure of traditional social policy and green economics then continue how the housing policy will be sustainable in this theoretical basis framework is discussed. In this study, it is emphasis that, even though traditional social policy objectives can be reached, the new approaches will be needed to be sustainable. Especially the measures, for efficient use of resources, which are failing in the world, need to be applied in houses, and obligation to establish self-sufficient buildings, hometowns and regions has been drawn attention to. It has been indicated that the high cost of this process will fall down because of evolving and cheaper technology day by day.
\end{abstract}

Keywords: $\quad$ Social Policy, Green Economics, Sustainability, Housing Policy, New Approaches

\section{Özet}

Bu çalışma sosyal politikaların en önemli araçlarından biri olan konut politikasına yeşil ekonomi perspektifinden bakmayı amaçlamaktadır. Çalışma, geleneksel sosyal politika yapısı ile yeşil ekonomi arasındaki bağı oluşturarak başlamaktadır. Ardından bu teorik temel çerçevede konut politikasının nasıl sürdürülebilir olacağ̀ tartışllmaktadır. Çalışmada, geleneksel sosyal politika hedeflerine ulaşılabilse de bunun sürdürülebilir olması için yeni yaklaşımlara ihtiyaç duyulacağına vurgu yapılmaktadır. Özellikle dünyada hızla tükenen kaynakların etkin kullanımına yönelik tedbirlerin konutlarda da kullanilmasl gerektiğine, kendi kendine yeten konutların, sitelerin, bölgelerin oluşturulmasının zaruretine dikkat çekilmiş̧ir. Bu sürecin yüksek maliyetlerinin ise her gün gelişen ve ucuzlayan teknoloji sayasinde düşeceği belirtilmiştir. 


\section{Introduction}

This study has been written with the intention of bringing a new approach to the traditional social policies. For the last 30 years, the world has taken attention to the destructions done to the environment, and focuses on the unsustainability of the main stream economics ideologies. In this context, especially the green economics improving its theoretical infrastructure day by day carries on some studies to make the world a more habitable place and enables the current resources to be used longer. Also, social policy takes part in this context. Social policy, as a scholarship related to the welfare and welfare distribution, is one of the fields which most need sustainability. This study does not generally focus on the relationship between green economics and the scope of social policy, but directly focus on the sustainability of housing policies, which are among the most important issues of the social policy. Restriction aims to point out the two important topics. The first one is to imply housing policies, which have not been appreciated and the good applications of which do not occur, from the view of Turkish social policies, and the other is to touch on the topic of greening housing policies which is emphasized nowadays by social policy and green economics dual that has been argued approximately for fifteen years. In this context, after drawing the framework of traditional social policy scope, what green economics is and the relationship between the housing policy and green economics have been mentioned and the new approaches about housing policies on a sociopolitic base have been stated.

\section{The Scope of Traditional Social Policy}

Due to the fact that, the prior concern of this article is not the pure social policy, we will just settle to give general definition in this section. As is known, policies are used in all types of organizations. When these policies are formulated and implemented by the government, we call them Public Policies
(Midgley and Livermore, 2009). Public Policies can use sweeping area in Public weal. When these policies begin to use to enhance peoples' welfare or well-being, traditionally we begin to call them as Social Policies.

Although Social Policies seem basically the governmental policies, governments are of course affected by some mechanisms which are called interest groups. These groups may line up as trade unions, professional associations, business lobbies, nonprofit groups, state and municipal governments, and local communities (Midgley and Livermore, 2009).

Social policies are not deprived of theoretical base. It has close relationship with academic field and nearly a 50-year history. The first department of Social Policy was established at the London School of Economics in 1950, headed by Richard Titmuss (Ackers and Abbott, 1996). But of course its mental fundamentals had been based on before. In general, early pioneer of the study of social policy is accepted as Auguste Comte. He believed that scientific methods could be applied not only to explain natural phenomena but also to analyze and improve social conditions. As an academic field of study, Social Policy discipline was significantly influenced by the social welfare issues and institutional structures of the welfare state in the early years (Ackers and Abbott, 1996).

As can be seen in all, Social Policy scholarship basically involve two aspects: one of them is actual policies and programs of governments that affect people's welfare, the other is academic field of inquiry concerned with description, explanation and evaluation of this policies (Midgley and Livermore, 2009).

\section{Social Policy Concerns}

Traditionally Social Policy is briefly the study of social services and welfare state. The social services are mainly understood to include social security, housing, health, social work 
and education. It is called as the "Big Five" (Spicker, 1995). Spicker asserts that social policy is intimately concerned with the activities of the "Big Five" which make up the classic welfare state (Alcock, 2004). Again according to Spicker and Hill the big fives are both important in social policy with employment, prisons, legal services or drains. Of course it cannot be considered as universal rule. Most of social policy writers pay attention different issues. Some of them consider that policies concerned with employment rightly belong to the field of economics and economic policy rather than social policy, others consider that this policy might compromise just income maintenance and social security, health policy and services, the personal social services, education and training, employment and housing policy (Alcock,2004).

The other important issue in the terms of social policy context is "Third Way" discussion. Although it has variety of theoretical basis (Gamble and Kelly, 1998; Blair, 1998; White, 1998 etc) generally, context of modern paradigm of Third Way is based on Giddens' "Beyond Left and Right" (1994) and "The Third Way" (1998).

According to Giddens Third Way represents the renewal of social democracy in a changed, 'globalized' environment where the solutions of the old left have become redundant while those of the Right are reactionary (Giddens,1998). Actually this paradigm precisely does not lie between Left and Right but is beyond Left and Right (Giddens, 1994; Giddens, 1998). Third way does combine them in significant new ways, with policy implications that break with established debate and alternatives (Surender, 2004). It's not related to the economic systems (Liberalism or Socialism). It is just related to ideologies (Left And Right) (Driver and Martell,2000).

Third way is configured to rebuild deteriorating balance between rights and responsibilities. As in Giddens' Manifesto: "prime motto for the new politics, no rights without responsibilities" (Giddens, 1998:65). White, one of the other pioneer of the Third Way Paradigm, emphasizes that 'opportunity, responsibility and community' are the central rhetorical trinity of Third Way Politics (White, 1998 and 2004). But the contemporary author Le Grand adds one another more: Accountability (Le Grand, 1998). He calls this cuarta" as "CORA". Community, Opportunity, Responsibility and Accountability ${ }^{1}$.

In fact, the Third Way model is the umbrella of the changing welfare understanding. Transformation from the welfare to workfare process is the most obvious evidence of this. Workfare system intends -through individualized case- work support on the one hand and sanctions for non-compliance based on the withdrawal of social assistance benefits, on the other- to combine hassling and help; to engender a kind of 'Tough Love' (Dean, 2004; Jordan 2000). Welfare state which includes helps without responsibilities has begun to transform opportunity and responsibility substantial agreement with workfare. It clearly means "Third Way".

Besides all these, the world inevitably became interested in another important issue densely. Sustainable Development. Actually although it is not a new topic, increasing pollution of the world and depletion of resources has become important for this issue. And Green economics is the most important theme of the Sustainable Development.

Social Politics are not to be expected remain same in this conjuncture. The world changes rapidly and social policy must adapt to this changing in the same speed.

\footnotetext{
* 'Cuarta' is a Spanish term. In English it can be translate as 'quarter'

1 Community: Education,training and access to employment social inclusion/exclusion.

Community is to build on new structures and sovial investment guaranteeing opportunity and on indivitual responsibility.

Responsibility is not the same as self reliance, individuals are not expecter to be entirely self-sufficient under all cirsumstances.

Opportunity and responsibility as the means of achieving sovial inclusion and recitalized communities.
} 
Despite such all apparent differences and wide area, we accept the basic social politics context like these: Housing Policy, Health Policy, Education Policy, Employment Policy, Family Policy, Food Policy, Criminal Justice Policy.

Although these are all accepted as the Social Policy's infrastructure this article basically aims to assert this inevitable changing effects on the specific Social Policy instrument: Housing policy in the terms of Green Economics.

\section{General Description of Green Economics}

Green economics brings to economics the core drivers of ecology, equity, social and environmental justice (Kennet ${ }^{*}$ and Heinemann, 2010). Green economics is multidisciplinary, complex and holistic methods as well as taking into account the political and social aspects. According to Kennet and Heinemann, green economics is beginning to take shape with some of philosophical principles. It is distinctive in six ways that build on much older ideas which have involved being influenced by the full spectrum of more recent thinking. These are: Enlightenment, Critical Theory, Ideas about Structure and Institutions, Post Modernism, Feminist and Eco-feminist Economics/Ideas, The influence of the Limits to Growth PerspectiveGreen Economics and Nature.

Green economics is an alternative approach to think about economics in a world where our actions are beginning to have huge implications for the natural environment. It highlights the inter-dependence of human civilization and natural ecosystems, and considers the impact that our own decisions have on all aspect of life on earth (Kennet, 2007). It is not just about the environment. It is about efficiency in economics (Heinemann 2010).

The aim of Green Economics is to create a new discipline which works for the benefit of all people everywhere, for the planet, the biosphere,

\footnotetext{
* Miriam Kennet is Founder and General Director of Green Economics Institute, Oxford, UK.
}

non human species, nature, and other life forms. Green economics integrates ideas and theories which are also designed to help to end the systemic and institutional causes of inequity and poverty (Kennet, 2010)

The concept is as complex as it is timely. It is inclusive in all senses valuing not great wealth or riches, but diversity, sustainability, caring, sharing and sensitivity for all of life on earth including our own and those of others (Kennet, 2010).

Research in Green Economics typically aims to find solutions to problems such as, climate change, resource depletion, poverty, inequality, damage to ecosystems, loss of biodiversity and population pressure (Kennet 2007).

\section{Housing Policy and Green Economics}

As we mentioned before social policy is the subject mostly related to the welfare or welfare state. As an important branch of Social policy, housing policy has also the similar purpose with the main aims. Green economics is mainly related to sustainability. And the sustainability means real welfare for the new economics study.

In this section, we are going to examine the context of traditional housing policy and then we will try to keep connections between housing policy and green economics in the context of the changing face of social policy.

Housing is one of the most basic needs for people. Although the housing needs also take part in the lower steps at Maslow Needs Pyramid (as an example from the best known hierarchy of needs), historically housing policy as a social policy issue, was one of the last discussed problems in Welfare states.

According to housing history, although it is known before the 1914 period, it has become important after the First World War (Malpas and Murie, 1990). In the earliest of Century the 
vast mass of urban householders was private tenants and their landlords were middle class business people and professionals who invested in housing as a safe way of saving (Alcock, 2004). After the First World War the old structure was nearly destroyed. Then, the housing need has been tried to be resolved in a variety of ways. Of course it should be noted that the protest had an important role in this process. For example, when the protest of workers against the profiteering of their landlords in sensitive industrial areas, forced the Lloyd-George government to act in UK, British political agenda received serious attention on housing policy (Alcock, 2004).

During the inter-war years ( $1{ }^{\text {st }}$ and $2^{\text {nd }}$ World Wars) housing policy developed on two fronts: the control of rents in the private rented sector and subsidy of local authority building. After 1945 , its policy was the subject of an inter-party consensus. In this term, two types of development for housing can be talked about: Building Societies and State Actions.

Building Societies was related to self-help principle which is to be one of tools of social policy. People have created Building Societies independently of the state to a self-help solution to housing conditions (Alcock, 2004). The mechanism runs like this: members who formed societies commit themselves to make regular savings which are used to build houses until a sufficient amount has accumulated. They continue to pay until the last house is completed. After all houses are completed, the society is terminated. This practice is still continuing in most of the countries (as in Turkey) under the name of "Housing Cooperatives".

State actions consisted council housing. After 1945 council housing played a very important role on reconstruction. Briefly, the council housing is a way of meeting housing need for people whose ability to pay is too low and who are not able to afford a reasonable quality of housing in private housing market. To achieve this aim, houses which have begun to be called as 'council housing' have been rented to the people from the rent levels which are low enough to make it affordable (Pickvance, 2003).

Of course these two types of housing policies are not the only policies in Social Policy area. It must be remembered that becoming a homeowner affects a huge area and social life. So its concept has been extended toward a variety of main types of tenure.

For example "Housing Associations" are one of the enterprises of them. These are non-profit organizations which generally provide rented housing to groups with particular needs, such as elderly or young people. They were both funded by government budget (largely and on condition that they kept rents below certain levels in order to appeal to low-income households) and private funding. Their difficulties increased after 1988 when they came under government pressure to expand). Then they have diversified their activities considerably into housing management and urban regeneration, and even into providing market housing (Pickvance, 2003). But due to higher rent levels and pressures of higher interest rates on private sector loans, just $63 \%$ of housing association tenants in England received housing benefit in 2000 .

There are two more main types of tenure which are to be subject to housing and social policy. These are Owner-occupation and Private Renting.

Owned-occupation or home ownership has an important role in social policy agenda due to its variety of effects. One of the well known effects is on governments' tax policies and also on the mortgage systems or on unemployment. Sense of confidence is also the other effect which is corresponding with basic principles of welfare states' perception.

As a macro economic problem, home ownership is supported by governments with tax reliefs. By cheapening the cost of houses, this tax relief increased demand and had the effect of keeping house prices higher than they would otherwise be (of course depends on the 
size of tax relief, interest rates or level of income tax), since the supply of houses responds very slowly to changes in prices. The effects of abolishing were to raise government tax receipts and to lower house prices (Pickvance, 2003).

When people are supported with the Mortgage system, some inevitable results emerge in the markets. First of all the disposable incomes of people who loans banks or the others mortgage financiers, reduce sharply. This means reducing consumption expenditures. A liberal capitalist system never likes the reducing consumptions because it has mainly been established upon this structure. Also the decrease in the disposable income leaves people vulnerable to any unexpected situation. And they lose their payment ability in a short time.

Here, we should also mention that there is a close relationship between home-ownership and unemployment according to some of the researches' determinations which are based on European Statistics. For example Oswald has put forward a hypothesis arguing that the cost and inflexibility of home-ownership prevents rapid adjustment to employment change and thus creates unemployment (Oswald, 1999).

One of the other effects on employment which we mentioned may be evaluated from the point of the ownership with loan (mortgage) as above and the other is paid up ownership.

If the house is bought with loan, these people will do their best to avoid losing their jobs. Otherwise they cannot pay the loan. For that reason sometimes they can accept the jobs from the secondary labor force market too because exigencies affect the flexibility in job selection in a negative way. Also these exigencies cause the people to behave more rationalist. And this rationalism leads to reduce the crime rates inevitably because if people are sent to jail due to committing an illegal act, they will not be able to pay the loan anymore and their family will lose their house and it will consists a big damage more than expected. When considered from the broad perspective, having a house with mortgage or similar financial instrument supports the policy of fight against crime in a roundabout way which is the other branch of social policy.

Debtless home-ownership can cause totally opposite to this situation. The home owner may not rush to find a new job when they leave their jobs. It is even possible to a voluntary unemployment in a period. Because they have homes to live in and can bear as long as they pay the bills and for food.

Last but not least, homelessness also needs to be mentioned here. Although homelessness can't be defined so easily, 'rooflessness' meets its meanings in general. Or in accordance with the scope of the issue, the people who are squatting, and living in hostels for the homeless run by charities or by local councils (Pickvance, 2003).

In recent years, homelessness policy began to compel most of the governments, especially the one in the UK. People are searching open doors to take advantage of social protection shield. In 2002, a new Homelessness Act was passed in UK and its coverage has been extended from the certain types of care level in 18-20 age group to16 and 17 -year- old youths. Also the "pregnant women priority" has been known since 1985 by people. Maybe it can explain why this many young women are pregnant or have a baby/child in the UK.

Henceforward, the relationships between social policy and green economics will be mentioned from the viewpoint of sustainability of social policies.

As it is known, everything is linked to sustainability and optimal consumption in the green perspective. Resources are depleting day by day and we have to use energy, weather, forests and even air more carefully as than we did in past. Given this case, let's look the housing policy in this framework.

For a moment, let's suppose that the housing policy system has run perfectly. The state can provide the dwelling for 'needer' easily and 
optimally. So, can we really provide the welfare or reach the main aims of Social Politics? Or will we face different problems in the current economic structures?

For a moment, let's suppose that everybody has comfortable houses where they keep their families. They can have warm up easily, they can have a bath whenever they want, and they can water and mow the lawn in their yard with pleasure. Eventually, everything is going well and everybody seems to be happy including the state, because it has achieved its holy mission and raised the bar of welfare state and social policy.

After this sweet dream let's come back to the real world where we have been talked upon since 1980's. We have happy people now but our reserves are failing rapidly. Because everybody consume gas (or oil or coal or trees) for heating comfortably, and water for bath or their yard. And houses are lit up like a Christmas tree. In the meantime, let's suppose that the state warned them rigidly and tried to tell them in a variety of ways not to consume the resources loutishly, and also some people had already been realized this danger and were struggling to warn the others.

What must we think at this time? Are people, as members of a more developed world, closer to rational human beings who are partaking in the ultimate form of capitalism?

In other words, 'invisible hand' (or groups who have committed themselves to tell the people chock down this unconscious consumption all around the world or menacing the state's quite visible hands) can make the world more habitable place enough even though the successful implementation of social policies?

Of course No! And all these questions and this answer shows us that the social policy implementations need re-organization to break loose the traditional sense of welfare in accordance with the requirements of the sustainable world. In that case, these arguments need to come up in a broad perspective to correlate green economics and social policy.

\section{The New Approaches to Housing Perception and Conclusion}

In recent years, smart/self-sufficient ecological houses, towns and even cities are among the popular topics of the agenda. Indeed, these entities provide the discipline of energy and wastes are obviously important for the resources consumption and sustainable structure. Merging with social policies and housing policies which are running for fulfillment, the humans' most basic needs will be an important expansion to determine the future's social policy.

To carry on the effective and sustainable housing policy, local potentials based energy production, water recycling systems or the self -heating/cooling house technologies must be improved.

Of course all of these have a cost. But technology is developing and becoming cheaper day by day. For example, solar water heating technology has become cheaper and convenient. It is not surprising anymore to see this type of equipment at roofs of thousands of families even in low income groups.

Under these circumstances, it is necessary to provide incentives for the creation of the essential equipment to minimize the use of resources, place waste water storage and conversion equipment to the houses in certain periods and popularize the self-sufficient house zones. Establishing the local energy sources equipment (by using solar and wind) to the home/towns will be inevitable to be able to maintain the housing policy in the future.

Even if they seem as distant targets in these days, it must be remembered that having electricity or city water supply or washing/dishwashing machines in every home are not centuries-old tradition. 
Human being has marvelously evolved with industrialization in the past century. This evolution indicates that an ecological transformation is quite possible. Today, developed countries which are trying to merge the modern life style and natural life can establish very large and effective environmental areas. Some of the people can think that developed countries can do that because they have enough budgets. But what about the less developed countries?

Maybe we can answer this reasonable question by taking advantage of usage rates of electronic goods. Today there are millions televisions, DVD players, washing machines and dish washers in the world. And about half of this equipment is outside Europe, United State and Japan. Today, people have televisions and the other equipments in their homes even they earn less money (working poor effect) because these are obtainable goods now. But fifty years ago, a television or the similar equipments were too expensive for the average income family and it was nearly a dream to have them. But today, we almost cannot remember those days.

So, it is not a distant dream to reach the common self-sufficient home technologies as it is thought. But states must reorganize their housing policies in accordance with this perspective. Social policy can only keep its effectiveness in the future only by adopting such approaches. 


\section{References}

Alcock, C. (2004), Social Policy, Third Edition, Oxford University Press.

Annetts, J. Alex, L, McNeish W, and Mooney G.(2009), Understanding social welfare movements (208-209 the greening of social welfare: towards eco-feminism), UK, Social Policy Association.

Crook, T. and Kemp. P.A. (2011), Transforming Private Landlords: Housing, Markets and Public Policy, Oxford: Wiley-Blackwell.

Dalhgren, P. and Whitehead, M. (1991), Policies and Strategies to Promote Social Equity in Health. Stockholm, Institute of Future Studies.

Dean, H. (2004), Implications of Third Way Social Policy, Welfare State Change: Towards Third Way? Ed.J. Lewis and R. Surender, Oxford University Press.

Driver, S. and Martell, L.(2000), "Left, Right and the Third Way" Policy and Politics, Vol: 28 No:2 147-161, Policy Press.

Giddens, A.(1994), Beyond Left and Right. Cambridge: Polity Press.

Giddens, A.(1998), The Third Way, The Renewal of Social Democracy, Cambridge: Polity Press.

Goldman L. (1968), The Philosophy of the Enlightenment the Christian Burgess and Enlightenment, London, Routledge and Kegan Paul.

Hawthorn G.(1976), Enlightenment\&Despair: A History of Sociology,Cambridge University Press.

Jordan, B.(2000), Social Work and the Third Way: Tough Love as Social Policy. London: Sage.

Kennet, M. and Heinemann, V.(2010), “Green Economics, Introducing this progressive economics discipline" The Green Economics Reader, Green Economics Institute, UK.

Le Grand J.(1998), The Third Way Begins with CORA, New Statesman, 6 March: 26-7.

Oswald, A. (1999), The Housing Market and Europe's Unemployment: a Non Technical Paper, Coventry: Warwick University Press.
Pickvance, W. (2003). Home-Ownership and changing housing and mortgage markets:

The new economic realities, Housing and Social Change East-West Perspectives Ed.by Forrest,R. and Lee,J.(162-182).

Surender, R. (2004), Modern Challenges to the Welfare State and the Antecedents of the Third Way, Welfare State Change: Towards Third Way? Ed.J.Lewis\&R.Surender, Oxford University Press.

Welfare State Change: Towards Third Way? Ed.J.Lewis\&R.Surender, Oxford University Press. 